DOCTORS' ORDERS

N 



\title{
DOCTORS' ORDERS
}

\author{
The Making of
}

Status Hierarchies in

an Elite Profession 


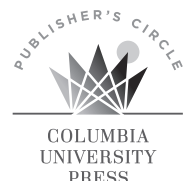

Columbia University Press gratefully acknowledges the generous support for this book provided by a member of our Publisher's Circle.

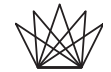 \\ Columbia University Press \\ Publishers Since 1893 \\ New York Chichester, West Sussex \\ cup.columbia.edu \\ Copyright @ 2020 Tania M. Jenkins \\ All rights reserved \\ Cataloging-in-Publication Data available from the Library of Congress. \\ ISBN 978-0-231-18934-7 (hardback) \\ ISBN 978-0-231-18935-4 (trade paper) \\ ISBN 978-0-231-54829-8 (ebook) \\ LCCN 2019057510 \\ Columbia University Press books are printed on permanent \\ and durable acid-free paper. \\ Printed in the United States of America \\ Cover design: Noah Arlow \\ Cover image: Getty Images
}


To Maman Louise

N 
